\title{
SZEREPTÉVESZTÉS MEGTÁMOGATVA \\ AZ ÁLLAM MAGÁNJOGI SZEREPKÖRÉNEK ANOMÁLIÁI
}

\author{
Zoványi Nikolett ${ }^{17}$
}

Az állam közjogi státuszát tekintve a legföbb szuverén, vagyis a legföbb hatalom gyakorlója állampolgárai és területe felett, a nemzetközi közjog szabályai által immunitást élvezve más államok beavatkozása alól. A hatalom gyakorlása számos jog mellett azonban kötelezettségeket is ró az államra és szervezetére, amely kötelezettségek teljesitése adott esetben kivitelezhetetlen vagy gazdaságtalan a saját szervezetrendszerén belül. Gondolunk itt különösen a lakosság közszolgáltatásokkal, közjavakkal való ellátására. Az államnak e kötelezettségei teljesitése érdekében a magánjog területén is számos esetben félként kell megjelennie, polgári jogi jogviszonyokat létesít. Ennek keretében polgári jogi szerzödéseket köt a gazdaság szereplőivel, gazdasági társaságot alapít vagy annak tevékenységében tagként, részvényesként részt vesz, adott esetben kárt okoz állampolgárainak, vagy éppen a piaci versenyre hatást gyakorló magatartást fejt ki ezen folyamatokban való megnyilvánulása során.

A magánjogi viszonyok egyik legfontosabb alapelve és sajátossága azonban a felek mellérendeltsége és egyenjogúsága. Különösen igaz ez a felek számára legnagyobb akaratautonómiát biztosító szerződési jog területére. Annak érdekében tehát, hogy az állam a privátszféra szereplőivel szerződéses kapcsolatokat létesíthessen, magát mellérendelt félnek kell, hogy tekintse.

\section{Egyenlötlen pozíciók a koncessziós szerződésekben}

Az állam bizonyos, az állam kizárólagos tulajdonában álló vagy az önkormányzati törzsvagyonhoz tartozó vagyontárgyak használatának, hasznosításának jogát a gazdasági élet szereplőinek engedheti át a koncessziós szerződések szabályainál fogva, díjfizetés ellenében. Az állam közjogi és magánjogi szerepének keveredésének egyik legszembetűnőbb példáját éppen ennek a szerződésnek a léte adja. Az államot olyan többletjogok illetik meg a koncessziós szerződés szabályai alapján, mint az egyoldalú szerződésmódosítás joga, a szerződés azonnal hatályú felmondásának joga és kiterjedt ellenőrzési jog.

Mindezeken túl a köz érdekeinek védelmét szem előtt tartva adott esetben egyben közjogi szereplőként is feltünik, összemosva ezzel a közjogi és magánjogi szerepkörének határait. Így például hatósági jogkörében bírságot szabhat ki a koncessziós szerződésben szereplö partnerével szemben, annak szerződésszegése esetén, illetve a koncesszor szerződésszerü teljesítését akadályozó, adott esetben kizáró egyéb szankciót is alkalmazhat.

Annak ellenére ugyanakkor, hogy az állam és egy gazdasági szereplő magánjogi szerződéséről van szó, amely a felek mellérendeltségét és egyenjogúságát hangsúlyozza, valahol elismerést kell nyernie a szerződés speciális tárgyának, a közérdek védelmének, és ezáltal a teljesítés kikényszerítéséhez megfelelő eszközöket kell az állam kezébe adnunk.

Szerepek keveredése

\footnotetext{
A tanulmány a Magyar Tudományos Akadémia és a Debreceni Egyetem Állam- és Jogtudományi Kar közös, MTA-DE Közszolgáltatási Kutatócsoportjának a Területi közszolgáltatások szabályozásai címü projektje keretében készült. A projekt leírására 1.: Horváth M.T.: Szempontok a területi közszolgáltatások regulációs változásainak vizsgálatához. In: HMT (szerk.) Kilengések. Közszolgáltatási változások. Budapest: Dialóg Campus, 2013. 9-25. old.

${ }^{17}$ Zoványi Nikolett, DE-ÁJK munkatársa
} 
$\mathrm{Az}$ állam adott esetben maga sem tudja eldönteni, hogy adott jogviszonyban mellérendelt jogalanyként vagy a közhatalom gyakorlójaként szándékozik fellépni. Ugyanakkor komoly dilemmát jelent, hogy bár a hatósági szerződések szabályanyaga jelentősen és több ponton is eltér a polgári jog kontraktusokra vonatkozó dogmatikájától, a hazai bírói gyakorlat - a Kúria döntése nyomán - egyértelmüen magánjogi szerződésként tekint rájuk. Kétségtelen, hogy ez a bírói felfogás elsősorban a bíróságok eljárási lehetőségének, hatáskörének megalapozására szolgál, azonban egyben az állammal szerződő privátszereplő oldalán is komoly garanciát jelenít meg.

Ez a garancia abban áll, hogy az állam által alkotott - és ebből következően módosítható jogszabályok védőhálója mellett a magánjogvita lehetőségét is megnyitja a felek számára. A gyakorlatban azonban látható, hogy az egyszerünek tünő alaptétel ellenére az ilyen ügyekben ítélkező bíróságok maguk is sokszor válaszút elé kerülnek, és az állam szuverénként vagy magánjogi félként való megjelenését nehezen védhető és gyakran inkoherens kritériumok mentén próbálják különválasztani.

\section{Az állam társasági tulajdonosi mivoltjának alapja, az állami társasági tulajdoni érdekeltség jellege}

A hatályos jog az állam gazdasági társaságokban való részvételére vonatkozóan - legalábbis a társasági jog alapításra, szervezetre, müködésre irányadó szabályai tekintetében - a társult tagok egyenlőségének elvéből eredően nem határoz meg különös rendelkezéseket. Első ránézésre így az állam gazdasági társaságokban való részvételét a magánjog szabályai megkülönböztetés mentes formában rendezik. Az állam társasági tagságának, társaságokban való részesedésszerzésének alapja azonban számos versenyerős szektorban megkérdőjelezhető.

A gazdasági társaságok lényegi sajátossága a tagok gazdasági érdekeinek kiszolgálása, mely vagyonszerzésben nyilvánul meg. A forprofit társaságok ennélfogva a nyereségszerzési cél által vezérelve határozzák meg üzletpolitikájukat, és a társasági jog által kínált intézményi keretek is ezt a megközelítést szorgalmazzák. A Ptk. alapvetően rugalmas szervezeti és müködési szabályai ${ }^{18}$ a gazdasági társaságok vonatkozásában nagyon szük körben, jellemzően a társaság hitelezőinek, munkavállalóinak, esetleg a kisebbségi tagoknak a védelme érdekében korlátozzák a tagok gazdasági érdekeit kiszolgáló és középpontba helyező működést. Az állam társasági részvétele azonban ideális esetben más indíttatású. Első megközelítésben valamely közhasznúsági érdek kiszolgálását kell, hogy megjelenítse, azaz a nyereségszerzés csupán a társaság hermetikusan elzárt közegében minősül célnak; az itt keletkező nyereség ugyanis állami feladatok ellátását biztosítja, és a társaság müködése is ilyen célokat kell, hogy kiszolgáljon. A társaság struktúrája és müködése azonban - a társasági jog szintjén - mégsem különbözik a privátszféra szereplői által müködtetett társaságokra megállapított szabályoktól. Magyarországon ráadásul olyan gazdasági szektorokban is jelen volt és van nem egy esetben többségi vagy kizárólagos állami tulajdonnal működő társaság, ahol az állam/állami vállalat létét nem indokolhatja valamely közszolgáltatás biztosítása.

\section{Információs aszimmetria}

Az állam magánjogi fellépése esetén is áttörhetetlen akadályt jelent, hogy számára minden esetben többletinformációk állnak rendelkezésre. A jogok legfőbb letéteményeseként és jogalkotóként olyan információk birtokába jut, mely információkhoz nincs hozzáférése a gazdaság más szereplőinek, így nemzeti és nemzetközi viszonylatban is olyan adatok, tények, információk megszerzésére van lehetősége, melyek alapvetően határozzák meg cselekvésének irányait, jogalkotási tevékenységét. Lényeges és kiemelendő, hogy nem csak címzettje ezen

\footnotetext{
${ }^{18} 2013$. évi V. törvény a Polgári Törvénykönyvröl, 3:4. § (3) bek.
} 
információknak, hanem alakítója is egyben a jogszabályi környezetnek, kijelöli a jogalkotás irányvonalait és intézkedéseket foganatosít az érvényesen elfogadott és hatályos jogszabályok végrehajtása iránt. Az államot ezért sohasem lehet abszolút elkülöníteni közjogi és magánjogi fellépései során.

\section{Állami szervek piaci magatartásának értékelése}

A gazdasági magánjog lényeges szabályzójaként a versenyjog hazai szabályanyaga az állammal - amennyiben nem a részvételével működő valamely vállalkozásról van szó - nem számol. Az állam megjelenése ennek ellenére akár a szerződéses kapcsolatban, akár közhatalmi tevékenységét gyakorolva, akár egy gazdasági társaság köntösébe bújva mindenképpen jelentős hatást gyakorol a piaci versenyre, mely hatás számos esetben negatív, a piaci versenyt torzító, korlátozó lehet.

Érdekes kérdést vet fel ezért az is, hogy mennyiben lehetnek alanyai a versenyjognak az állami szervek, amikor versenyjogilag értékelhető piaci magatartást fejtenek ki. A GVH gyakorlata alapján, ha az állam szervei, illetve az állam részvételével müködő vállalatok magatartásuk jellege folytán - közhatalmi tevékenységük terjedelmét túllépik vagy piaci magatartást fejtenek ki tevékenységükkel, a versenyjog alanyának minősülhetnek, és velük szemben alkalmazható a versenyjog szankciórendszere. ${ }^{19}$

\section{Kiterjedt immunitás állami szerveknek közhatalmi jogkörben okozott károk megtérítése során}

Az állam magánjogi fellépésének és közjogi magatartásainak is egyik legjelentősebb, a társadalmat és a jogtudósokat leginkább megosztó területe az állam kártérítési felelősségének és perelhetőségének kérdése. A '90-es évek óta a közigazgatási károkért való felelősség leginkább megosztó kérdése a bírói gyakorlatban kialakult kirívó jogsértés tana, amely megnehezíti a jogérvényesítést, védelmi ernyőt kínálva a közigazgatási szerveknek. A felróhatóság eltérő mércéjének alkalmazása révén ezen tevékenységek érdemi részét jelentő magatartások értékelése kerül a felróhatóság fogalmán kívülre. A megoldást egy egységes és kiegyensúlyozott felróhatósági mérce kialakítása jelenthetné, mely figyelembe venné a jogalkalmazási és jogértelmezési tevékenységek speciális voltát.

\section{Záró gondolatok}

Az állami immunitás terjedelmének, az állami jogi személyiség mibenlétének meghatározása nem egyszerü feladat. A legtöbb helyzetben igazságtalannak tünő megoldás hasonló tényállás mellett igazolhatónak látszódhat. Az állam szerződéses viszonyainak értékelésekor, magánjogi magatartásainak elemzésekor úgy véljük, hogy elsősorban a felek magánjogi viszonyának sajátosságaira kell figyelemmel lenni, azonban igyekezni kell az egyensúly megtalálására a közérdek megfelelő védelmének biztosításához is.

A piacgazdaságok müködésének egyik legfontosabb feltétele a jogbiztonság léte, éppen ezért törekedni kell a jogszabályi környezet és a jogalkalmazási gyakorlat állandóvá és következetessé tételére. Nem az jelenti ugyanis a legnagyobb és leginkább aggasztó problémát, ha a magánjogi viszonyokban - a mellérendeltség és egyenjogúság elvét sértve az államnak többletjogokat adunk, hanem az, ha a jogszabályok és a jogalkalmazás kiszámíthatatlanná és a gazdasági folyamatokat indokolatlanul hátráltatóvá válnak, ezáltal pedig az állam saját érdekeit szolgálja ki a közérdek helyett.

\footnotetext{
${ }^{19}$ Ld. 83/1998. Vj., 164/1998. Vj., 48/1998. Vj., 100/2002. Vj.
} 